Dye S, Brown S, Chhina N (2009) Seclusion and restraint usage in seven English psychiatric intensive care units (PICUs). Journal of Psychiatric Intensive Care 5: 69-79.

Gibson R, Fenton M, Coutinho E, et al (2004) Zuclopenthixol acetate for acute schizophrenia and similar serious mental illnesses. Cochrane Database of Systematic Reviews issue 3: CD000525.

National Collaborating Centre for Nursing and Supportive Care (2005) Violence: The Short-term Management of Disturbed/Violent Behaviour in In-Patient Psychiatric Settings and Emergency Departments. National Institute for Clinical Excellence.

Schleifer JJ (2011) Management of acute agitation in psychosis: an evidence-based approach in the USA. Advances in Psychiatric Treatment 17: $91-100$.

Taylor D, Paton C, Kapur S (2010) The Maudsley Prescribing Guidelines (10th edn). Informa Healthcare.

\title{
Excerpts from The Letters of Dostoyevsky to His Wife, by Fyodor Dostoyevsky
}

IN OTHER WORDS

\section{Selected by Sanju George}

In 1867, just two months after their marriage, Dostoyevsky and his wife Anna Grigorievna fled to Dresden, to escape his gambling debts. From there he went alone to Homburg to play roulette. The excerpts below are from his letters to Anna written from Homburg.

Sunday 19 May. 10 a.m.

'Yesterday was a very horrid day for me. I lost far too heavily (judging relatively). What am I to do my angel? Gambling is not intended for a man with nerves like mine. I played for about ten hours, and ended by losing. I lost during the day and won again. [...] as soon as I begin to win, then immediately I take risks. I cannot control myself [...].'

Monday 20 May. 10 a.m.

'The main thing about it all is, that it is so senseless, stupid and vulgar and yet I cannot tear myself away from my idea, i.e. I cannot leave absolutely everything and return to you. [...] Can you believe me? I lost everything yesterday, everything to the last kopeck, to the last gulden, and in the end I decided to write to you at once to ask you to send me some money for my journey home. But I remembered my watch and I went to the watchmaker either to sell or to pawn it; it is a terribly common practice here, i.e. in a gambling town.'

\section{May. 10 a.m.}

'Anya my dear, my friend, my wife, forgive me [...]. Can you, will you respect me now? And what is love without respect? Our very marriage is shaken by this. Oh! My friend, don't condemn me completely! I loathe gambling, not only now, at this moment, but yesterday, and the day before yesterday I cursed it [...]. Our circumstances are bad enough as it is, and yet I have wasted money on this journey to Homburg and lost more than 1000 francs - nearly 350 roubles. It is a crime!'
Fyodor Mikhailovich Dostoyevsky (1821-1881), widely regarded as one of the best 19th-century Russian writers, is perhaps less known for his gambling addiction. Dostoyevsky battled this addiction, or 'cursed monomania' as he called it, for several years. He eventually recovered, but not before it had strained his marriage, finances and psychological health. The excerpts here are from The Letters of Dostoyevsky to His Wife (translated from Russian by Elizabeth Hill \& Doris Mudie) Constable \& Co, 1930

doi: 10.1192/apt.17.2.103 